\title{
Techniques of Eyebrow Lifting: A Narrative Review
}

\author{
Nasser Karimi, MD, MPH; Mohsen Bahmani Kashkouli, MD; Hamed Sianati, MD; Behzad Khademi, MD
}

Eye and Skull Base Research Centers, The Five Senses Institute, Iran University of Medical Sciences, Tehran, Iran

ORCID:

Mohsen Bahmani Kashkouli: https://orcid.org/0000-0003-0347-5549

\section{Abstract}

None of brow lift techniques are completely satisfactory because of their limited effectiveness, lack of longevity, and potential complications. The aim of this study was to provide a comprehensive review of the literature on the pros and cons of the most popular techniques in brow and forehead lift. Relevant original articles in the PubMed database (English language) were sought using the search terms "eyebrow lift", "forehead lift", "periorbital rejuvenation", "eyebrow ptosis", "blepharoplasty and eyebrow change", "surgical eyebrow lift", and "non-surgical eyebrow lift", No date limitation was considered. Titles and abstracts were scanned to include the most pertinent articles. Subsequently, full texts of included articles (111 articles) were skimmed and finally 56 references were selected for the review. A narrative synthesis of data was finally undertaken with particular attention to the indications, techniques, and common complications of the eyebrow lift procedures. Ten popular techniques including two nonsurgical methods (Botulinum toxin A and soft tissue fillers) were reviewed in this article. In general, non-surgical methods of forehead/brow lift are temporary, need less experience and correction would be easier should any complication occur. Surgical methods are divided into three categories: trans-blepharoplasty eyebrow lift, direct eyebrow lift, and trans-forehead eyebrow/forehead lift. Currently, the most popular method is the endoscopic forehead lift approach even though its longevity is limited. Direct brow-lift is particularly useful in patients with facial palsy and those who are more likely to be accepting of the scar (male gender, high forehead hair line).

Keywords: Blepharoplasty; Endoscopy; Esthetics; Eyebrow; Forehead; Lifting; Rejuvenation

J Ophthalmic Vis Res 2020; 15 (2): 218-235

\section{INTRODUCTION}

Although each operation is customized to the patient's individual senile changes, most patients

Correspondence to:

Mohsen B Kashkouli, MD. Eye and Skull base Research centers, The Five Senses Institute, Iran University of Medical Sciences, Rassoul Akram hospital, Niayesh Ave., Sattarkhan St., Tehran 14456, Iran.

E-mail: mkashkouli2@gmail.com

Received: 24-05-2019 Accepted: 29-02-2020

\section{Access this article online}

Website: https://knepublishing.com/index.php/JOVR

DOI: 10.18502/jovr.v15i2.6740 looking for blepharoplasty procedure have a component of eyebrow ptosis with or without asymmetry. ${ }^{[1]}$ Therefore, the knowledge of surgical anatomy and interventions for brow and forehead rejuvenation are critical for an oculo-facial plastic surgeon. ${ }^{[2]}$ In contrast to upper and lower blepharoplasty, with a standard technique ${ }^{[3,4]}$ adopted and applied almost universally,

This is an open access journal, and articles are distributed under the terms of the Creative Commons Attribution-NonCommercial-ShareAlike 4.0 License, which allows others to remix, tweak, and build upon the work non-commercially, as long as appropriate credit is given and the new creations are licensed under the identical terms.

How to cite this article: Karimi N, Kashkouli MB, Sianati $\mathrm{H}$, Khademi $\mathrm{B}$ Techniques of Eyebrow Lifting: A Narrative Review. J Ophthalmic Vis Res 2020;15:218-235. 
a multitude of surgical techniques are available to address eyebrow and forehead. These may be combined with upper blepharoplasty for stable, long lasting, and natural results. Recognizing each patient's individual attributes and matching them to the ideal rejuvenation techniques will allow for maximum aesthetic benefit. For instance while an old man with few hair on head and multiple deep horizontal forehead wrinkles may be satisfactorily treated with mid-forehead brow lift with relatively lower cost and recovery period, a young woman with abundant hair benefits most from endoscopic lift. As such the aim of this review was to elaborate on the indications, contraindications, advantages, and disadvantages of the common and current techniques in the management of eyebrow/ forehead ptosis.

\section{METHODS}

A review of current available literature was performed using PubMed database. We limited our investigation to English-language journals. The keywords for initial data bank searches included "periorbital rejuvenation", "eyebrow ptosis", "eyebrow lift", "forehead lift", "blepharoplasty and eyebrow change", "surgical eyebrow lift", and "nonsurgical eyebrow lift". There was no restriction on the date of publication. Titles were scanned by the senior author to include the most pertinent articles (233 articles). Abstracts were subsequently reviewed to select 111 articles to go through their full text. A narrative synthesis of data was finally undertaken, citing 54 articles and 2 books, with a special attention to the techniques of the eyebrow lift. We acknowledge the limitation that this is not a systematic review and we have certainly missed sound publications not indexed in Medline.

\section{Common and Current Methods of Brow Lift}

There are two categories of brow elevation and forehead lifts [Table 1]. Non-surgical methods of forehead/brow lift are temporary, require less experience, and in case of any complication, can be corrected easily. Surgical methods, on the other hand, include some with temporary effect (suture lift and trans-blepharoplasty approaches) and some with comparatively permanent effect (direct and trans-forehead approaches). Surgical techniques are generally more surgeon- and equipmentdependent and complications are more sophisticated.

\section{Non-surgical methods}

\section{Botulinum toxin A (BTA) injection}

The brow depressors are the orbital orbicularis oculi (lateral and mid-brow), procerus (medial brow), corrugators (medial brow), and depressor supercilli (medial brow). BTA may be used for eyebrow lifting by targeting both glabellar and crow's feet areas. ${ }^{[5]}$ It mostly results in lateral eyebrow lift [Figure 1]. Ahn et $\mathrm{al}^{[6]}$ showed an average elevation in the central brow of $1 \mathrm{~mm}$ and of $4.8 \mathrm{~mm}$ in the lateral brow. The effect is temporary and lasts for three to six months. ${ }^{[5]}$ Pain, asymmetries, bruising and ecchymosis, erythema and edema, headache, diplopia, focal facial paralysis, dry eye syndrome, blepharoptosis, exaggeration of wrinkles, and muscle weakness are some of the adverse effects that might be seen by BTA injection for the upper face. ${ }^{[5]}$

\section{Soft tissue fillers}

Fillers can enhance eyebrow contour and volume, and may be used for improving the elevation of the eyebrow tail in case BTA fails to provide desired eyebrow lifting. ${ }^{[7]}$ Hyaluronic Acid gels, the most frequently used fillers, are generally developed on the basis of two flow (rheological) parameters namely the GO (elastic modulus, stiffness) and viscosity. ${ }^{[8]}$ High-GO gels contribute to tissue vectoring (lifting) and resistance to deformation from the forces of gravity and facial movement. The viscosity of a gel is the ability to resist tissue spread. Thus, it contributes to contour stability. Fillers with high GO and high viscosity lead to a stable lift and fill effect and are best implanted deep (preperiosteal) for maximum effect.

To avoid inadvertent injection into the orbital cavity, one should first identify the orbital rim. The needle is positioned at the lateral end of the eyebrow; aspirated and then injected very slowly using a pre-periosteal bolus injection. Massage upward (to shape) is the next step. Injections in the lateral aspect of the eyebrows are intended to promote the support of the retro-orbicularis oculi fat [Figure 2]. Overcorrection of the eyebrow with filler can result in an unduly prominent eyebrow 
Table 1. Advantages and disadvantages of the different techniques for the eyebrow lift

\begin{tabular}{|c|c|c|c|c|c|}
\hline & Definition & Indications & Contraindications & Advantages & Disadvantages \\
\hline \multicolumn{6}{|c|}{ Non-surgical methods } \\
\hline $\begin{array}{l}\text { Botulinum toxin } \mathrm{A} \\
\text { injection }\end{array}$ & $\begin{array}{l}\text { To treat the } \\
\text { depressor } \\
\text { muscles of the } \\
\text { brow with BTA }\end{array}$ & $\begin{array}{l}\text { Desire to elevate } \\
\text { the lateral } \\
\text { eyebrow r with } \\
\text { a less invasive } \\
\text { method }\end{array}$ & $\begin{array}{l}\text { Hypersensitivity to } \\
\text { BTA }\end{array}$ & $\begin{array}{l}\text { Less invasive, less } \\
\text { expensive, no } \\
\text { major permanent } \\
\text { side effect }\end{array}$ & $\begin{array}{l}\text { Temporary effect } \\
\text { of the central and } \\
\text { lateral eyebrow, } \\
\text { little effect on } \\
\text { medial eyebrow }\end{array}$ \\
\hline Soft tissue fillers & $\begin{array}{l}\text { Injection of filler } \\
\text { in the lateral } \\
\text { eyebrow ro } \\
\text { promote support } \\
\text { of the retro- } \\
\text { orbicularis oculi } \\
\text { fat }\end{array}$ & $\begin{array}{l}\text { Improving the } \\
\text { elevation of the } \\
\text { eyebrow tail in } \\
\text { cases where } \\
\text { BTA provides } \\
\text { insufficient } \\
\text { eyebrow lifting }\end{array}$ & One eye patients & $\begin{array}{lr}\text { Fillers } & \text { can } \\
\text { enhance } & \text { eyebrow } \\
\text { contour } & \text { and } \\
\text { volume } & \end{array}$ & $\begin{array}{l}\text { Little effect on } \\
\text { medial eyebrow, } \\
\text { possibility of } \\
\text { serious adverse } \\
\text { events }\end{array}$ \\
\hline \multicolumn{6}{|l|}{ Surgical methods } \\
\hline Internal browpexy & $\begin{array}{l}\text { Anchoring of } \\
\text { the brow tissue } \\
\text { (muscle and/or fat) } \\
\text { to the periosteum } \\
\text { of the frontal } \\
\text { bone via a trans- } \\
\text { blepharoplasty } \\
\text { approach }\end{array}$ & $\begin{array}{l}\text { To limit post } \\
\text { blepharoplasty } \\
\text { eyebrow descent }\end{array}$ & $\begin{array}{l}\text { If formal brow "lift- } \\
\text { ing" is expected }\end{array}$ & $\begin{array}{l}\text { Avoids the cost } \\
\text { and morbidity of } \\
\text { more formal brow- } \\
\text { lifting techniques }\end{array}$ & $\begin{array}{l}\text { Modest efficasy, } \\
\text { tenderness, and } \\
\text { dimpling of the } \\
\text { brow }\end{array}$ \\
\hline $\begin{array}{l}\text { Glabellar } \\
\text { myoplasty }\end{array}$ & $\begin{array}{l}\text { To transect } \\
\text { the corrugator } \\
\text { supercilii } \\
\text { and procerus } \\
\text { muscles during } \\
\text { a blepharoplasty } \\
\text { procedure }\end{array}$ & $\begin{array}{l}\text { Complaints limited } \\
\text { to glabellar } \\
\text { folds and } \\
\text { dermatochalasis }\end{array}$ & $\begin{array}{l}\text { Limited forehead } \\
\text { lift }\end{array}$ & $\begin{array}{l}\text { Long-lasting } \\
\text { improvement of } \\
\text { vertical glabellar } \\
\text { rhytids at the time } \\
\text { of blepharoplasty }\end{array}$ & $\begin{array}{l}\text { Supratrochlear } \\
\text { neurovascular } \\
\text { bundle is at risk }\end{array}$ \\
\hline Direct brow lift & $\begin{array}{l}\text { Elliptical incision } \\
\text { immediately } \\
\text { above the brows }\end{array}$ & $\begin{array}{lr}\text { Facial } & \text { nerve } \\
\text { palzy, } & \text { men } \\
\text { with recessed } \\
\text { hairline, patients } \\
\text { who can not } \\
\text { undergo general } \\
\text { anesthesia }\end{array}$ & $\begin{array}{l}\text { If medial eyebow } \\
\text { elevation is partic- } \\
\text { ularly sought }\end{array}$ & $\begin{array}{lr}\text { The greatest } \\
\text { elevation per } \\
\text { millimeter of } \\
\text { excised tissue }\end{array}$ & $\begin{array}{l}\text { A faint suprabrow } \\
\text { scar }\end{array}$ \\
\hline $\begin{array}{l}\text { Tissue suspension } \\
\text { with suture }\end{array}$ & $\begin{array}{l}\text { Elevating the } \\
\text { superficial soft } \\
\text { tissue by self- } \\
\text { anchoring sutures }\end{array}$ & $\begin{array}{l}\text { Maybe suggested } \\
\text { as a minimally } \\
\text { invasive } \\
\text { procedure }\end{array}$ & $\begin{array}{l}\text { If patients asks for } \\
\text { standard of care } \\
\text { with proven long- } \\
\text { term efficasy }\end{array}$ & $\begin{array}{l}\text { Avoiding large } \\
\text { incisions and } \\
\text { greatly reducing } \\
\text { recovery time }\end{array}$ & $\begin{array}{l}\text { Little evidence } \\
\text { on long-lasting } \\
\text { aesthetic results }\end{array}$ \\
\hline $\begin{array}{l}\text { Coronal forehead } \\
\text { and eyebrow lift }\end{array}$ & $\begin{array}{l}\text { Coronal incision } \\
\text { extends between } \\
\text { the temporal } \\
\text { fossae, behind } \\
\text { the hairline, } \\
\text { followed r by } \\
\text { extensive tissue } \\
\text { excison/dissection } \\
\text { and lift }\end{array}$ & $\begin{array}{l}\text { Very heavy fore- } \\
\text { head with signifi- } \\
\text { cant tissue excess } \\
\text { and wrinkling }\end{array}$ & High hairline & $\begin{array}{l}\text { Extensive incision } \\
\text { with potentially } \\
\text { persistent hair loss } \\
\text { and numbness }\end{array}$ & $\begin{array}{l}\text { High efficacy, no } \\
\text { need for high-tech } \\
\text { equipment }\end{array}$ \\
\hline $\begin{array}{l}\text { Endoscopic } \\
\text { forehead Lift }\end{array}$ & $\begin{array}{l}\text { Three to five } \\
\text { small incisions } \\
\text { withing the hair- } \\
\text { bearing scalp, } \\
\text { with titrated upper } \\
\text { face dissection }\end{array}$ & $\begin{array}{l}\text { Procedure of } \\
\text { choice for } \\
\text { patients with } \\
\text { brow asymmetry }\end{array}$ & High hairline & $\begin{array}{l}\text { Small incision with } \\
\text { little risk of persis- } \\
\text { tent hair loss and } \\
\text { numbness }\end{array}$ & $\begin{array}{l}\text { Longer learning } \\
\text { curve, needs } \\
\text { endoscope }\end{array}$ \\
\hline
\end{tabular}


Table 1. Continued.

\begin{tabular}{|c|c|c|c|c|c|}
\hline & Definition & Indications & Contraindications & Advantages & Disadvantages \\
\hline $\begin{array}{l}\text { Trichophytic fore- } \\
\text { head and brow lift }\end{array}$ & $\begin{array}{lr}\text { Superior } & \text { incision } \\
\text { marked } & \text { along } \\
\text { hairline } & \text { and } \\
\text { involves } & \text { excision } \\
\text { of bare } & \text { forehead } \\
\text { skin } & \end{array}$ & $\begin{array}{l}\text { Brow ptosis and } \\
\text { high hairline }\end{array}$ & Short forehead & $\begin{array}{lr}\text { No } & \text { need } \\
\text { for } & \text { general } \\
\text { anesthesia, lowers } & \\
\text { the frontal hairline }\end{array}$ & $\begin{array}{l}\text { Chance } \\
\text { scarring, of } \\
\text { asymmetry, and } \\
\text { paresthesias of } \\
\text { the forehead and } \\
\text { scalp }\end{array}$ \\
\hline $\begin{array}{l}\text { Mid-forehead } \\
\text { brow lift }\end{array}$ & $\begin{array}{l}\text { Superior incision } \\
\text { marked along a } \\
\text { central forehead } \\
\text { crease and then } \\
\text { appropriate } \\
\text { amount of tissue } \\
\text { excised }\end{array}$ & $\begin{array}{lr}\text { Elderly } & \text { men } \\
\text { with } & \text { significant } \\
\text { brow } & \text { ptosis } \\
\text { that decreases } \\
\text { superior visual } \\
\text { field }\end{array}$ & $\begin{array}{l}\text { Patients with } \\
\text { unfurrowed } \\
\text { forehead }\end{array}$ & $\begin{array}{lr}\text { No } & \text { need } \\
\text { for } & \text { general } \\
\text { anesthesia, lowers } \\
\text { the frontal hairline }\end{array}$ & $\begin{array}{l}\text { Prominent } \\
\text { hyperemic scar, } \\
\text { less effective for } \\
\text { lateral brow ptosis }\end{array}$ \\
\hline
\end{tabular}
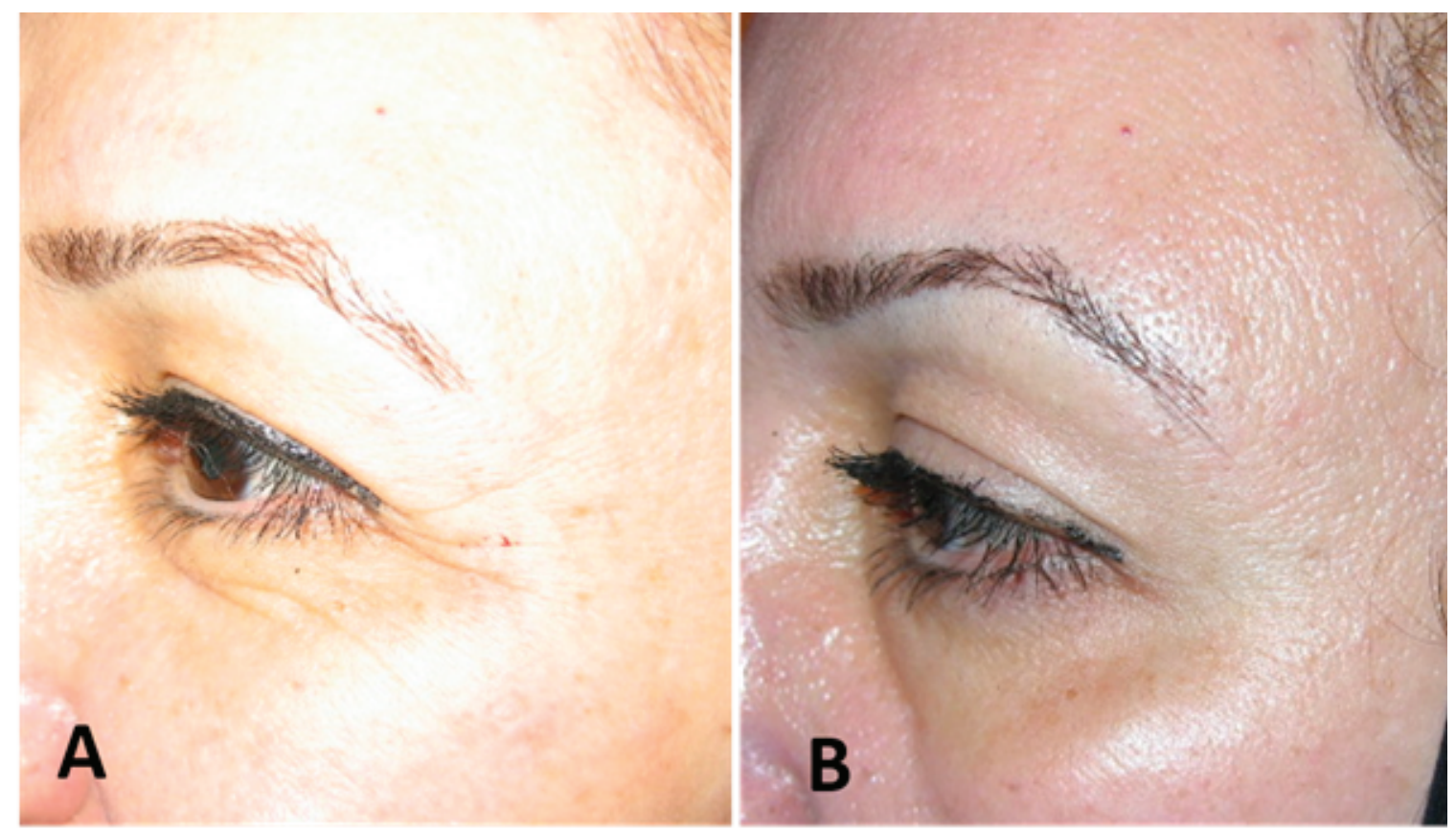

Figure 1. Before $(A)$ and after $(B)$ botulinum toxin A injection for the lateral eyebrow lift.

appearance or eyelid edema. The second injection should be given in the same manner medial to the first injection along the eyebrow. Supraorbital foramen should be respected. ${ }^{[9]}$

Erythema and ecchymosis, foreign body granulomas, and migration of filler material are among the complications that may happen with fillers. Serious adverse events with soft tissue fillers include infection, biofilm reaction, cutaneous vascular compromise (skin/tissue necrosis), and most worrisome, blindness from retrograde injection into the ocular arterial system. ${ }^{[10]}$

\section{Surgical Methods}

Surgical techniques [Table 1] generally either address the eyebrow ptosis alone (transblepharoplasty and direct approaches) or eyebrow and forehead together (trans-forehead approaches). In this section surgical techniques will be discussed in the following three categories: trans-blepharoplasty eyebrow lift, direct eyebrow lift, and trans-forehead eyebrow/forehead lift. While common complications of each procedure are listed, it should be noted that periorbital 


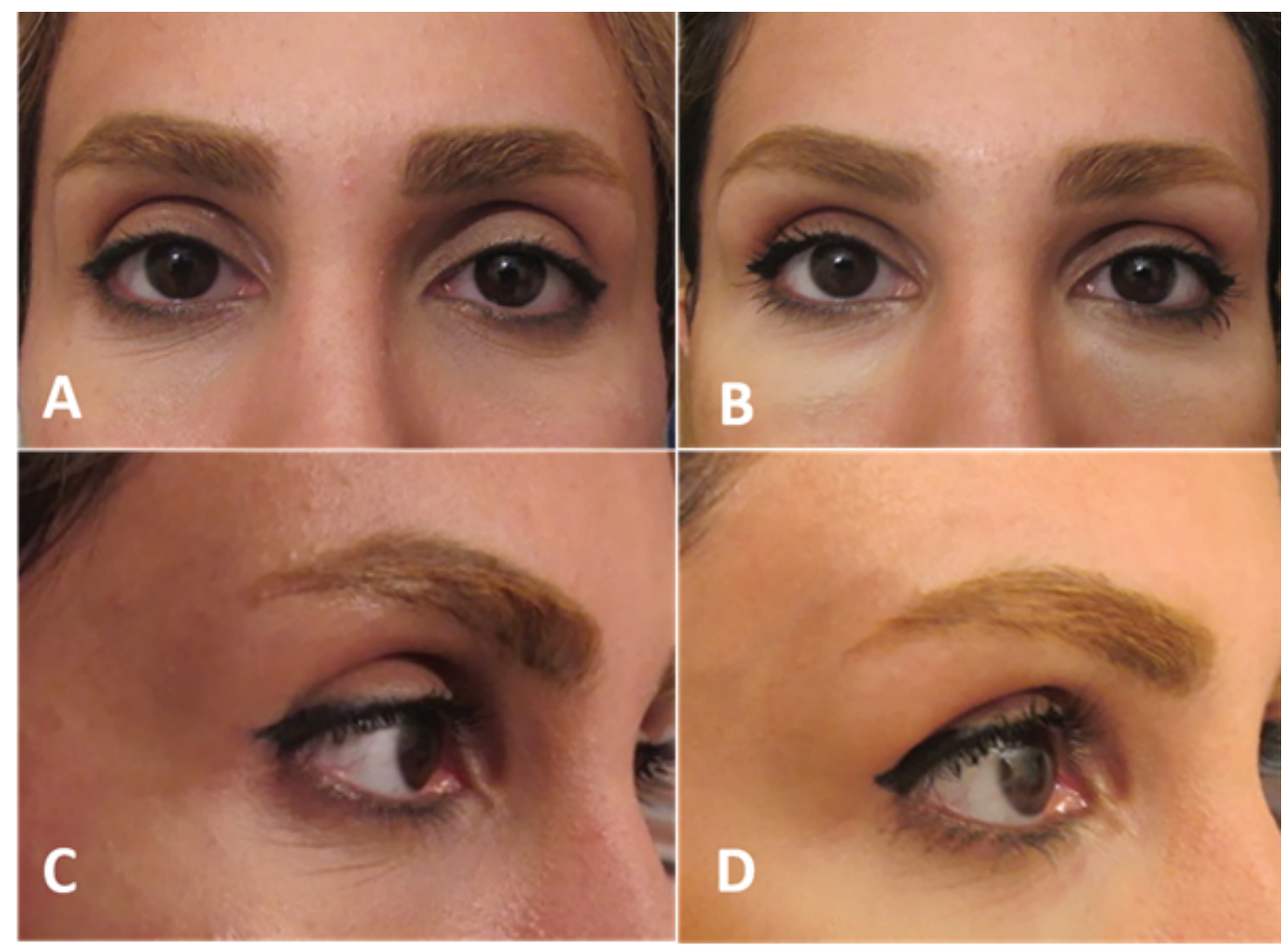

Figure 2. Before $(A \& C)$ and after (B \& D) Hyaluronic acid gel (filler) injection under the lateral $2 / 3$ of eyebrow. The injection yield to eyebrow projection especially in front view (B) and lift especially on lateral view (D).

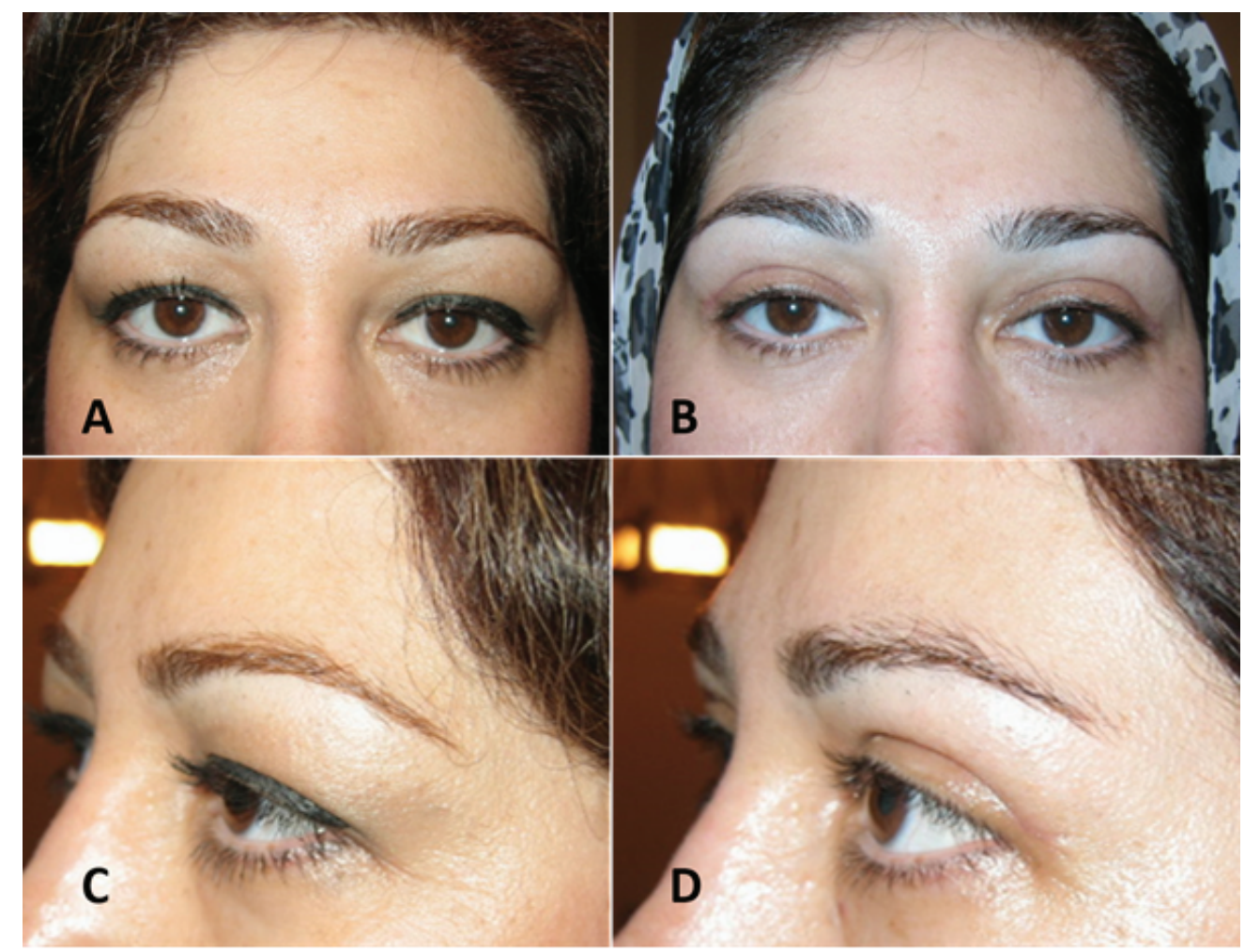

Figure 3. A gentleman before ( $A$ \& ) and six months after (B \& D) upper blepharoplasty and internal browpexy. Internal browpexy has resulted in no or minimal change in the eyebrow position. 
facial procedures may be followed by unexpected complications such as primary angle closure attacks. ${ }^{[11]}$ Thus realizing a few of most commonly encountered complications related to each procedure does not obviate the need to keep keen to thorough patient evaluation pre- and postoperatively.

\section{Trans-blepharoplasty approaches}

\section{Internal browpexy}

Temporal brow ptosis is a common aging change that can contribute to upper eyelid fullness. Stabilizing or lifting the outer brow has become an essential adjunct to aesthetic upper blepharoplasty. ${ }^{[12-14]}$ A browpexy, or brow suture suspension, is not a formal lift. This technique provides a minimally invasive way to provide stabilization and possibly subtle elevation of the lateral brow. ${ }^{[15]}$ It consists in a measured anchoring of brow tissue (muscle and/or fat) to the periosteum of the frontal bone (or bone itself) above the superior orbital rim. The internal approach of the procedure was first described by McCord and Doxanas in 1990. ${ }^{[14]}$ In this original description, the sub-brow tissue is accessed through a blepharoplasty eyelid crease incision and the brow fat pad is dissected free of the frontal periosteum at a variable distance from the orbital rim. A guiding suture can be placed from skin to the internal wound to ensure the appropriate placement of the suspension suture on the undersurface of the brow soft tissue. The area of brow suspension to the frontal bone periosteum is measured directly. A 4-0 Prolene, for instance, engages the periosteum and also the internal brow tissue at the predetermined area (typically the inferior brow). Two to three similar sutures are placed laterally. When all sutures are tied, the brow is anchored to the new position [Figure 3].

Mokhtarzadeh et al reported that internal browpexy led to an average elevation in lateral/central brow position of $2.29 \mathrm{~mm}$ and $1.47 \mathrm{~mm}$ (average follow-up of 4-5 months). ${ }^{[16]}$ As such, this study among others, ${ }^{[17,18]}$ validate the ability of browpexy techniques to obtain a modest elevation (rather than mere stabilization) of eyebrow position. However, these studies generally lack long-term follow-up and hence do not present more than intermediate-term success. Future studies targeted at longevity of effect would be of great value.

Brassiere suture technique is a variant of internal brow approach, in which the orbicularis oculi is sutured to the superior lateral orbital rim periosteum. ${ }^{[19,20]}$ Such adjunct may enhance the projection and fullness of the eyebrow rather than its elevation. ${ }^{[19]}$ After standard blepharoplasty ${ }^{[3]}$ skin excision, the orbicularis muscle and orbital septum are fully opened from nasal to temporal. Two 5-0 chromic sutures are placed from the inferior wound edge orbicularis to the superior orbital rim periosteum and to the superior wound edge orbicularis.

On the other hand, some authors have advocated partial excision of ROOF to decrease eyebrow fullness which is called browplasty. After standard blepharoplasty and skin excision, the dissection is extended in submuscular plane toward the eyebrow. Once the dissection extends approximately $1-1.5 \mathrm{~cm}$ above the superior and lateral orbital rim, the brow fat pad should be clearly identified and an elliptical piece of brow fat pad should be removed approximately 1-1.5 $\mathrm{cm}$ in vertical dimension tapering nasally and temporally. The fat pad should be removed at the level of periosteum; however, periosteum should be left intact. This technique may cause temporary parenthesis of lateral two-third of the eyebrow. ${ }^{[14]}$ In our view, this technique mostly suits patients with heavy eyebrow especially male gender and patients with thyroid eye disease.

Internal browpexy may achieve less lift than desired and the sutures may cause dimpling of the overlying skin. ${ }^{[21]}$ Temporary forehead hypoesthesia (usually resolving in weeks to months) is a common adverse effect because superficial branches of the supratrochlear, supraorbital, and lacrimal nerves are often transected. ${ }^{[18]}$ Restricted brow movement and irregular contours are other causes of dissatisfaction. ${ }^{[18]}$

\section{Glabellar myoplasty}

A subset of male patients may be pleased with their brow position and shape, yet request longlasting improvement of vertical glabellar rhytids at the time of blepharoplasty. An ideal approach 
in these patients may be blepharoplasty associated with glabellar myoplasty. ${ }^{[22]}$ Routine upper eyelid blepharoplasty is first performed and then attention is turned to the glabellar musculature. From the medial aspect of the upper eyelid compartment, dissection is then carried out superomedially in a supraperiosteal plane into the glabellar region. Care should be taken to avoid the supratrochlear neurovascular bundle. With retraction and direct visualization, the corrugator supercilii and procerus muscles are identified and transected with electrocautery. This procedure yields little if any improvement in brow position without a traditional brow lift procedure [Figure 4].

Glabellar myoplasty is usually ensued by more edema and ecchymosis compared to upper eyelid blepharoplasty, and less compared to conventional brow surgery. ${ }^{[22]}$ Occasional brow contour deformities may develop with overaggressive resection of muscle. ${ }^{[22]}$

\section{Direct Brow Lift}

The direct approach is most commonly used in patients with brow ptosis secondary to injury of the temporal branch of the seventh nerve. ${ }^{[23]}$ While cosmetic direct lift is mostly performed for men with recessed hairline who are thus not a good candidate for forehead-brow lift [Figure 5], it can be performed with good results in selected female patients who require only eyebrow tail elevation alone [Figure 6]. ${ }^{[24]}$ This procedure is simple to perform and the amount of brow elevation is predictable. It maximizes the lift obtainable for a given amount of tissue removal. Direct brow lift involves bilateral elliptical incisions just above the brows. The inferior border of the incision is marked along the superior line of the eyebrow. After digital elevation to the desired height, the pen marks the site of desired elevation. The brow is released, and the forehead is marked at the level of the marker pen to designate the superior border of the ellipse. ${ }^{[25,26]}$ Dissection is carefully performed superficial to the frontalis muscle, avoiding damage to the supraorbital nerve and vessels. With the direct lift, descent of the brow postoperatively may limit efficacy, particularly with the use of absorbable sutures and if there is sever preoperative ptosis. ${ }^{[21]}$ Postoperative decent of the eyebrow mainly occurs within the first postoperative year. ${ }^{[27]}$
Scars that are depressed or hypertrophic may ensue at the superior edge of the brow in a small percentage of patients, potentially requiring revision or camouflage. Laser resurfacing will often improve the scar appearance and may also increase the elevation. Paresthesia and numbness associated with damage to the supraorbital nerve are common complications and typically resolve in a few months. ${ }^{[21]}$ Booth and colleagues reported that $74 \%$ (32/43 brows) of patients experienced numbness and that $7 \%$ were dissatisfied with this complication. ${ }^{[25]}$ Complications related to sutures include granuloma formation at the site of braided absorbable sutures and suture abscess formation.

\section{Trans-forehead Approaches}

\section{Suture lift}

Sutures have been used to elevate lax skin of the neck and face, including the brow. ${ }^{[28-30]}$ With the advent of polypropylene barbed sutures, the capacity of sutures to withstand loads increased substantially. ${ }^{[31]}$ Facial lift by barbed sutures, with little or no soft tissue dissection, was first reported in the late 1980s by Russian authors Sulamanidze et al. ${ }^{[32]}$ These polypropylene self-anchoring sutures studded with numerous bidirectional (converging) barbs should be inserted into the subdermis, where the hook-like projections support and fix local tissue. Although numerous techniques evolved over the years, they all consist in the interposition of the soft tissues to the suture barbs, followed by inflammatory response and fibrosis [Figure 7]. The technique, in brief, involves a small incision made posterior to the hairline followed by undermining the forehead in the subcutaneous plane using a blunt-tipped cannula. Straight Keith needle with the attached thread is guided to exit just above the brow. The distal aspect of the sutures is trimmed so that the suture is beneath the skin. The Keith needle is removed, and the suture is locked into place. This is repeated along different spots, exiting above each eyebrow. The sutures are then contoured by stabilizing the threads and kneading the skin in a superior direction until there is significant elevation of the brow. There may be bunching of the skin at the hairline, but this resolves in three to six weeks. Proximally, the suture is tied down 


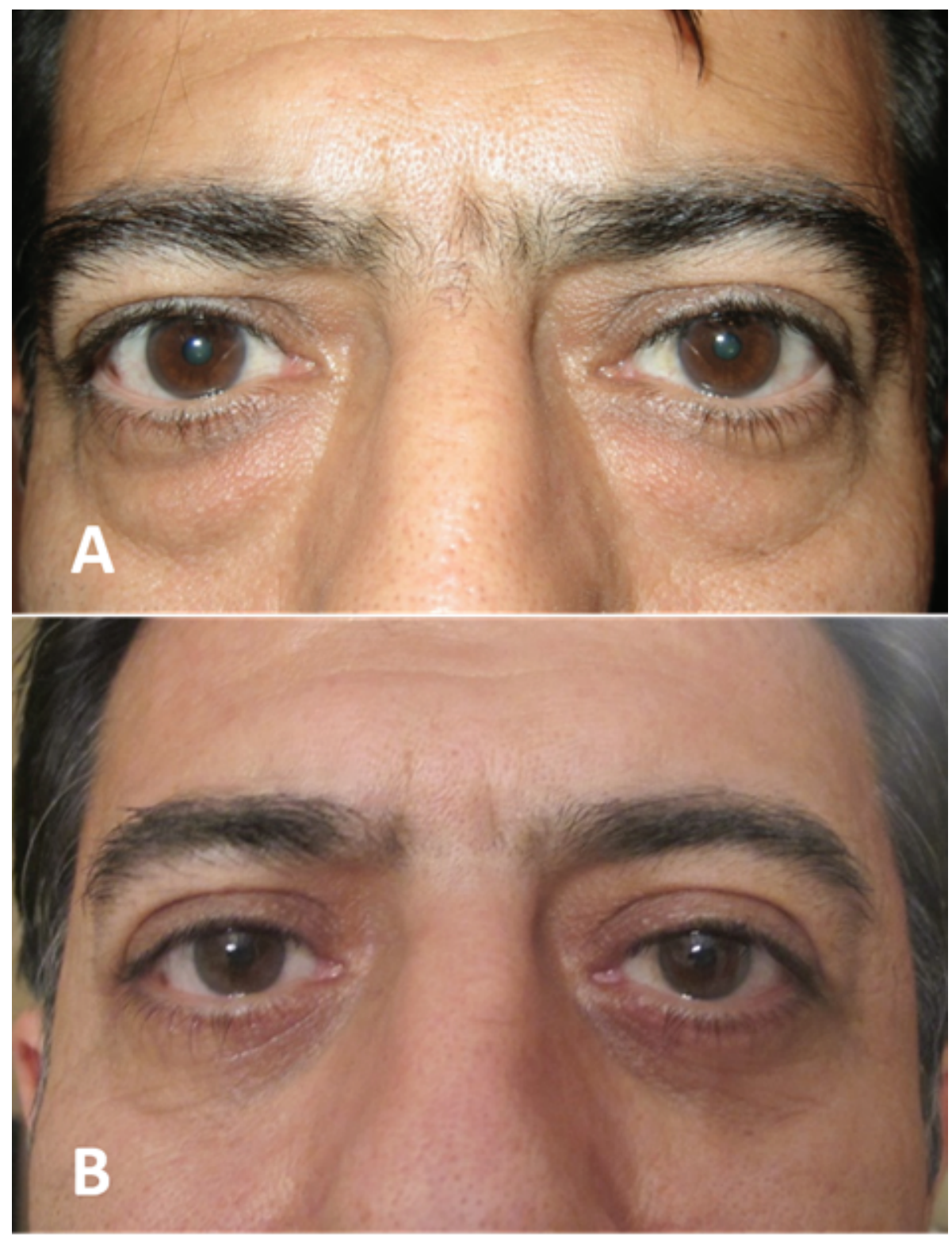

Figure 4. A patient before (A) and after (B) upper and lower blepharoplasty with trans-blepharoplasty corrugator excision. Transblepharoplasty glabellar myoplasty (corrugator muscle deactivation) leads to medial eyebrow lift.

by taking a bite of fascia. The small incision is then closed.

Despite the continued use, evidence on longterm efficacy of thread lift is rare. Lycka et al followed-up 117 patients for 12-24 months and revealed (by blind photo evaluation) that $70 \%$ of the initial correction was maintained. ${ }^{[28]}$ Although early reports of thread lift were promising in terms of efficacy and safety (follow-up to 2.5 years), ${ }^{[32,33]}$ this was not consistently supported by ensuing articles. Some optimistic articles lacked a clear efficacy time frame ${ }^{[34]}$ or suffered from a short follow-up. ${ }^{[35]}$ In a recent systematic review, ${ }^{[36]}$ authors demonstrated that, within the past decade, little or no substantial evidence has been added to the peer-reviewed literature to support thread-lift sutures in terms of efficacy or safety. In fact, all included literature in the review, except two studies (prone to conflict of interest), demonstrated none or very limited durability of the lifting effect. In consequence long-term efficacy of thread lifting remains doubtful. ${ }^{[37-39]}$ Notable described complications of barbed suture include facial asymmetry, ${ }^{[40]}$ thread migration, and extrusion. ${ }^{[41]}$ 


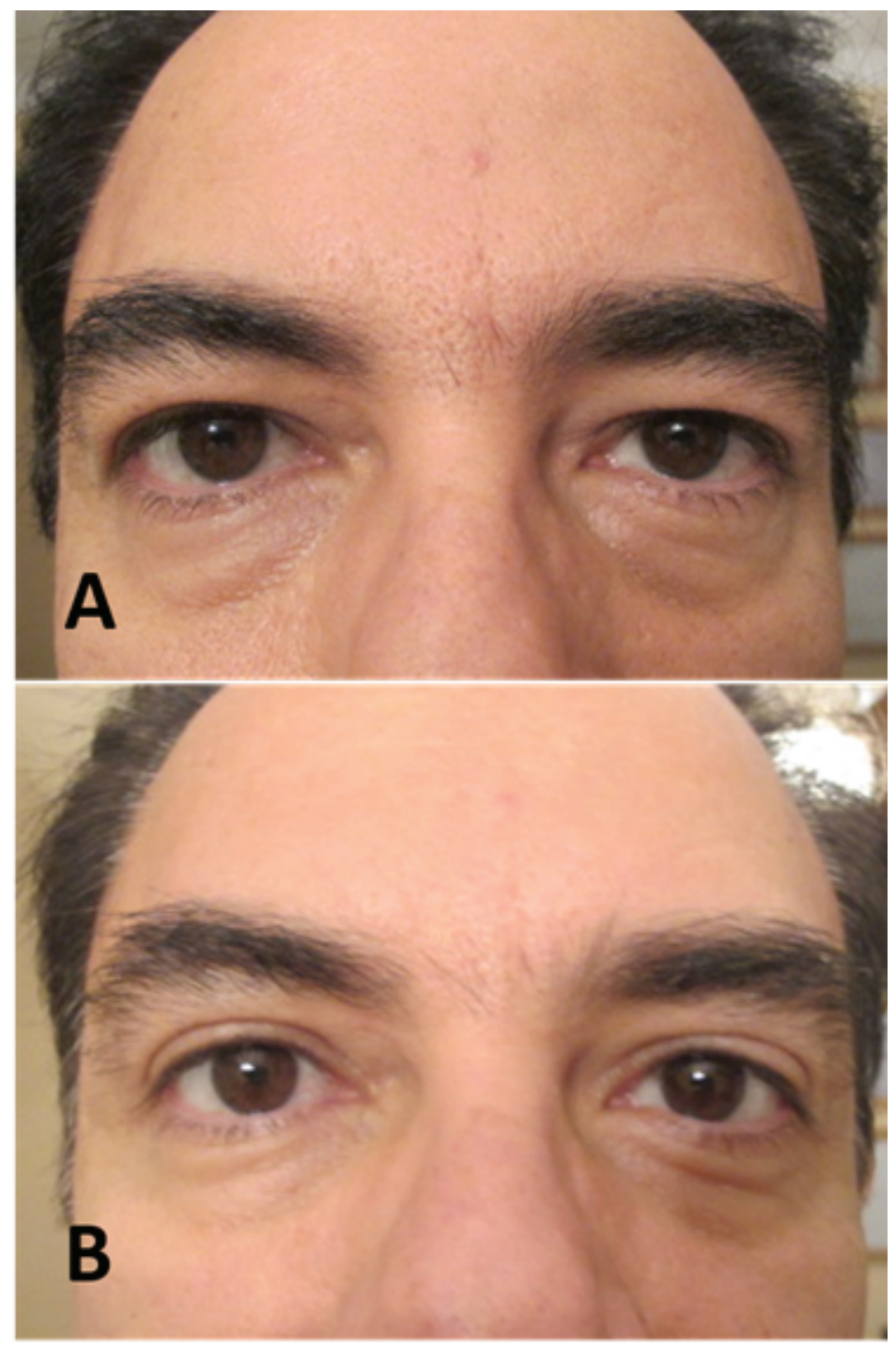

Figure 5. A subject with high hair line before $(A)$ and after $(B)$ direct eyebrow lift and upper blepharoplasty procedures. Direct eyebrow lift is mostly used for male with high frontal hair line which lateral eyebrow is lifted.

\section{Coronal forehead and eyebrow lift}

The open coronal brow lift was the benchmark for eyebrow-forehead rejuvenation for several decades. It is highly effective in elevating and contouring the brows and removing the foreheadglabella rhytids [Figure 8]. It is however contraindicated in patients with high frontal hairline. The incision is usually made posterior to the hairline and extends between the temporal fossae [Figure 9(A)]. The dissection extends down to $2 \mathrm{~cm}$ above the supraorbital rim [Figure $9(B){ }^{[26]}$ Most surgeons use a subgaleal dissection, $15 \%$ use subperiosteal dissection alone, and $12 \%$ use both planes of dissection. ${ }^{[42]} A$ procerus-corrugator myotomy is performed. is excised, and the wound is closed [Figure 9/CD)]. Potential complications include skin necrosis, infection, hematoma, and noticeable scarring. ${ }^{[43,44]}$ The location of the incision perpendicular to the sensory nerves often compromises the sensory nerves, which results in temporary or potentially permanent numbness anterior and posterior to the incision. ${ }^{[43,45]}$ The theoretical complication of alopecia is often cited as a deterrent to the coronal open procedure; nevertheless, a survey found merely a small difference in the rates of alopecia between coronal and endoscopic approaches (4\% vs $2.9 \%$. ${ }^{[46]}$ Although other reports suggest that temporary alopecia may be as high as 33\% in patients, typically resolves within three to six months. ${ }^{[47]}$ 


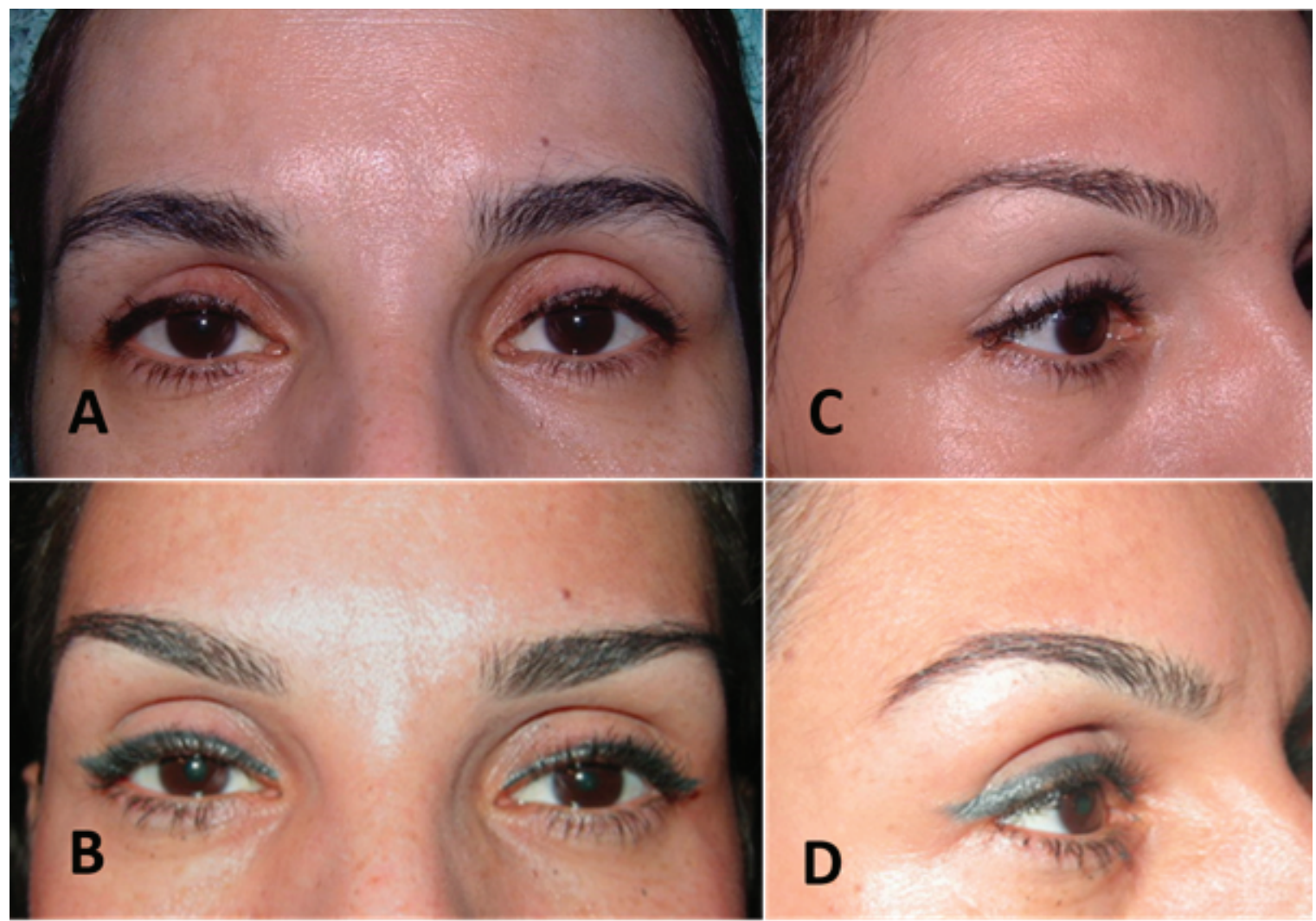

Figure 6. A very effective eyebrow tail lift with no visible scar $(B \& D)$ could be resulted from direct brow lift in female with high hairline $(A \& C)$.

\section{Endoscopic forehead lift}

For most patients, an endoscopic brow lift is preferable to an open coronal brow lift because it is associated with reduced scarring and patient morbidity in women [Figure 10] and men [Figure 11]. ${ }^{[48,49]}$ The endoscopic brow lift begins with marking the desired position of eyebrow elevation at the midline, lateral limbus, and lateral eyebrow. Five small scalp incisions, 1 to $2 \mathrm{~cm}$ in length, are typically made posterior to the hairline, three medially and two temporally. ${ }^{[4]}$ The medial incisions should be dissected dorsally, whereas the temporal incisions should be dissected toward the midline. In one survey, $39 \%$ of surgeons used a subperiosteal dissection, 13\% used the subgaleal plane, and $12 \%$ used some combination of subperiosteal and subgaleal. ${ }^{[46]}$ Dissection may safely be performed without direct visualization up to $2 \mathrm{~cm}$ of the orbital rim. Thereafter endoscopic view allows for careful identification of the supraorbital vessels and nerves [Figure 12]. ${ }^{[50]}$ While frontalis, corrugator, and procerus muscles are cut. Finally, the eyebrows are elevated, and tissue is fixed using a wide range of methods, including titanium or resorbable screws, fibrin glue, endotine, and suture with or without bone tunnels.

A survey of 21 plastic surgeons found that $70 \%$ of patients and $50 \%$ of plastic surgeons were satisfied with endoscopic brow lift results after at least two years of follow-up. ${ }^{[51]}$ Viksraitis and colleagues measured postoperative brow elevation using photographic and computer analysis. ${ }^{[52]}$ After at least six months of follow-up, median eyebrow elevation for 49 patients was $2.9 \mathrm{~mm}$ at the lateral canthus, $2.5 \mathrm{~mm}$ for the lateral limbus, $2.3 \mathrm{~mm}$ for the medial margin of the iris, and $2.2 \mathrm{~mm}$ at the medial canthus. Temporary injury may lead to temporary or persistent frontal numbness may follow. ${ }^{[53]}$ Postoperative headache was a common complaint in a study of 538 endoscopic brow lifts reported by Jones and colleagues. ${ }^{[54]}$

Endoscopic brow lift effectively elevates the medial, central, and lateral brow, and it seems to 


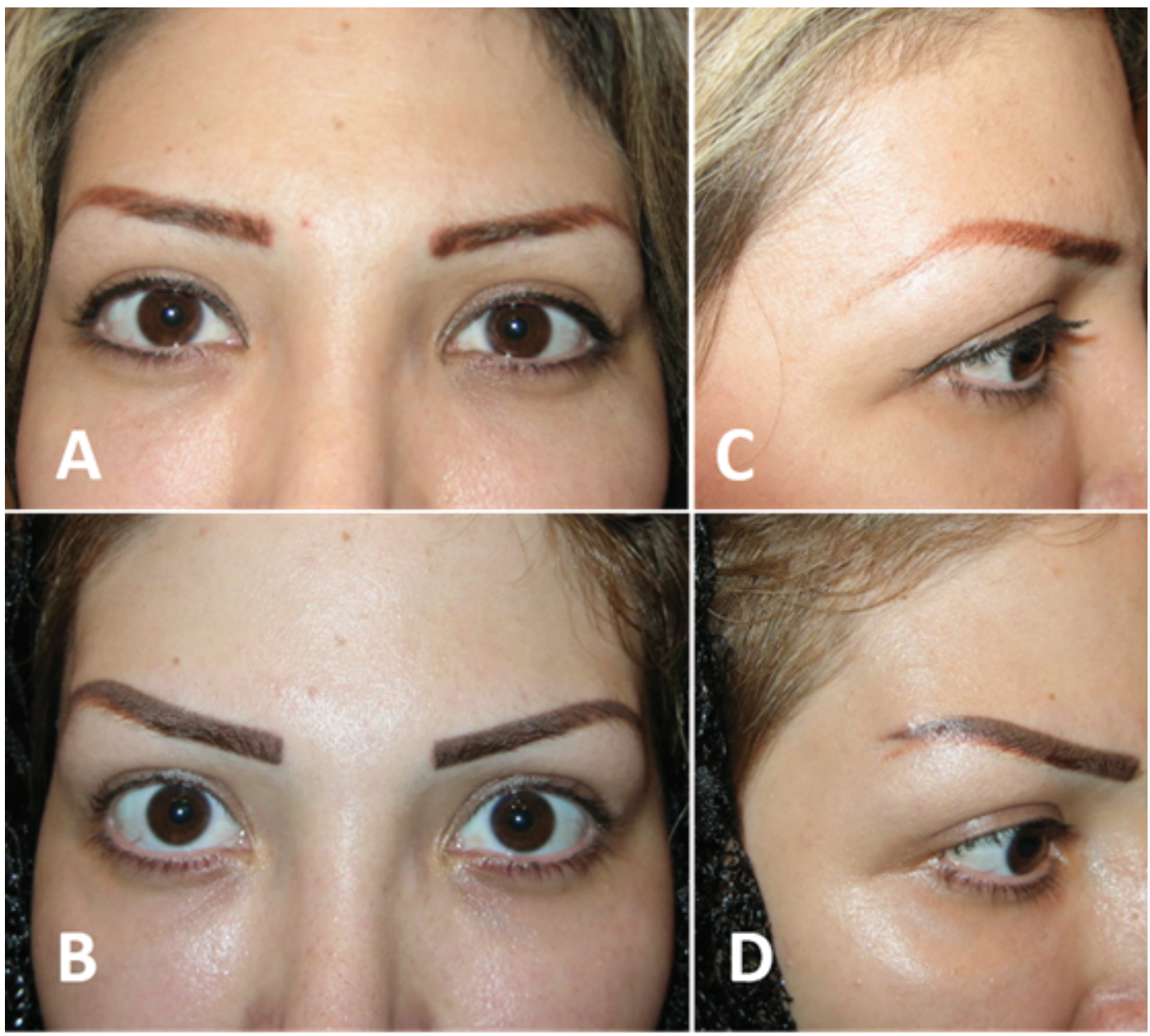

Figure 7. While suture (barbed) lift minimally elevates the eyebrow tail and consequently increased eyelid show (B \& D), the effect is temporary. It is usually performed in young females ( $\&$ \&) with realistic expectation.

be the most effective technique for improving brow symmetry and may be the procedure of choice for patients with more than $1.5 \mathrm{~mm}$ difference in average brow height. ${ }^{[55]}$ Moreover Permanent smoothening of deep glabellar lines could be effectively achieved through endoscopic upper face lift [Figure 13].

A modification of coronal forehead lift has been described as minimally invasive, non-endoscopic brow lift. This technique applies the same dissection level (subperiosteal) and incisions ( 3 or 5 post hairline incisions) as the endoscopic approach but endoscop is not utilized. The anatomical location of the supratrochlear and supraorbital neurovascular bundles at the superior orbital rim should be identified and marked preoperatively (e.g. via palpation of the supraorbital notch). Tabatabai et al reported comparable results to endoscopic lift. ${ }^{[56]}$

\section{Trichophytic forehead and brow lift}

In patients with a high hairline, forehead reduction as well as brow elevation may be achievable [Figure 14] via putting the incision at or $1-2 \mathrm{~mm}$ posterior to the hairline and excising the excess bare forehead later on in the procedure. ${ }^{[57]}$ To preserve the follicles at the edge of the wound (so that adequate hair is available for scar camouflage) the incision should be beveled in a posterior to anterior direction with minimal cauterization. The depth of incision and plane of dissection (subcutaneous, subgaleal, and subperiosteal) can be varied by surgeon's discren. The authors' preferred plane is the subperiosteal as it facilitates access to the corrugators and allows for better tissue release and hence maximal elevation. Dissection is continued anteriorly up to $1 \mathrm{~cm}$ above the superior orbital rim and along the lateral 

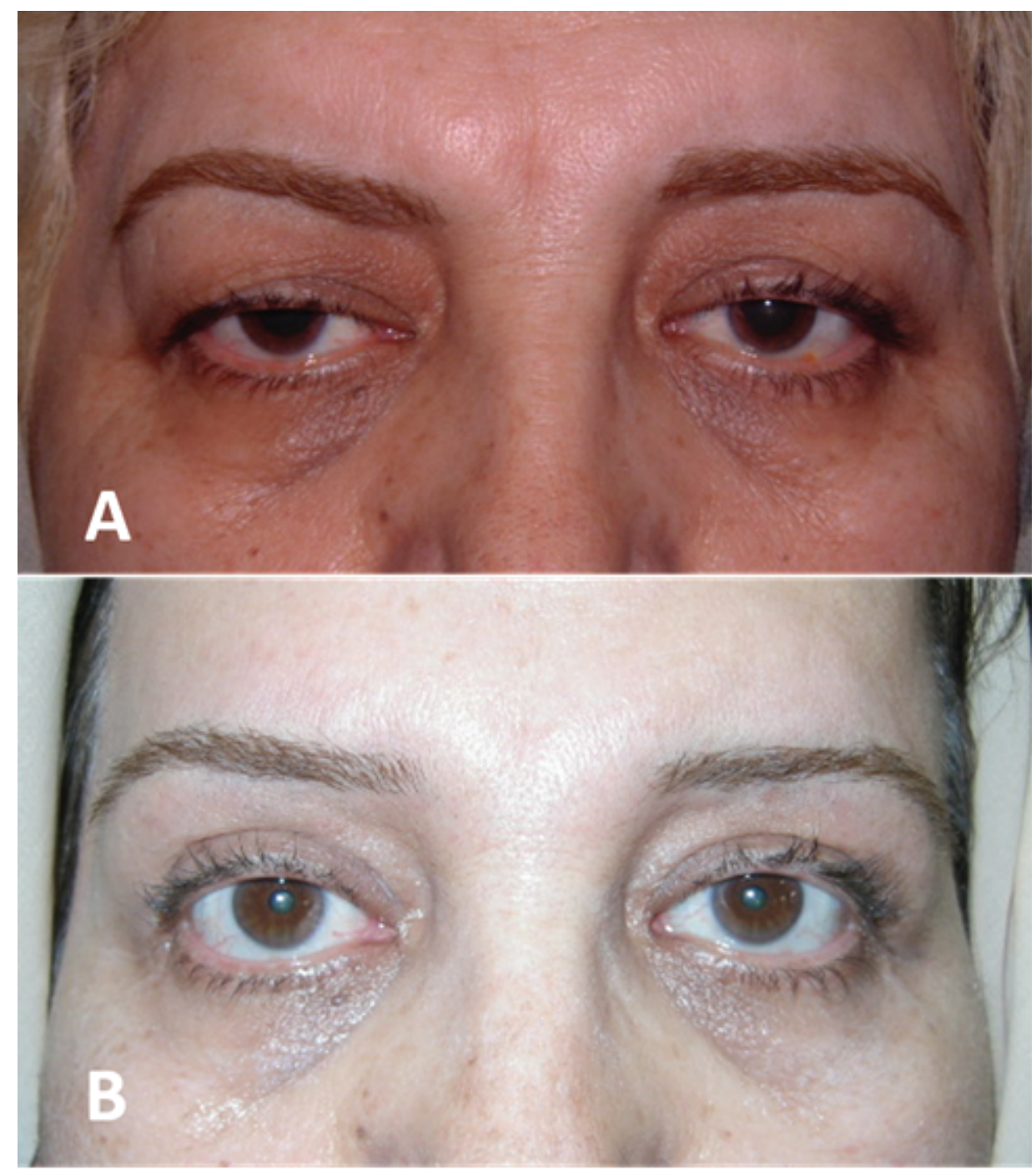

Figure 8. Before (A) and after (B) transcoronal lift with upper blepharoplasty and ptosis repair.

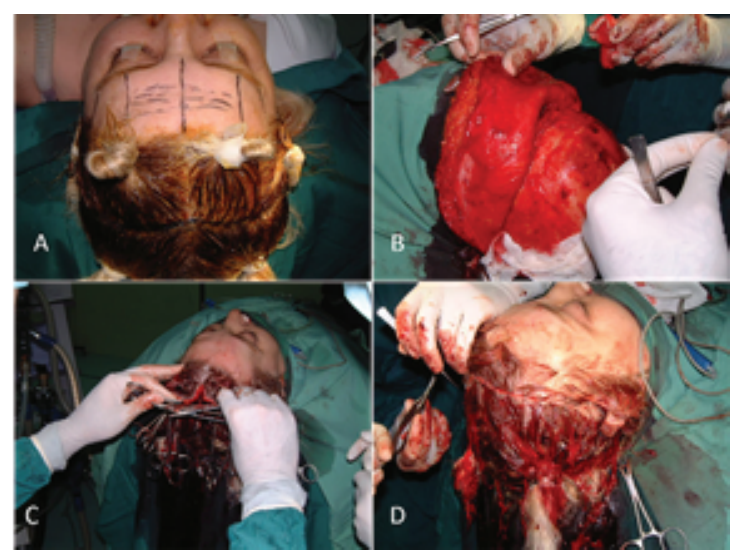

Figure 9. Cardinal steps of a transcoronal forehead lift include careful marking (A), complete release in the subperiosteal plane, up to the orbital rim (B), advancing the forehead flap over the scalp wound until the flap is moderately tight (C), and finally after excision of the excess segment and wound closure with staples (D). 


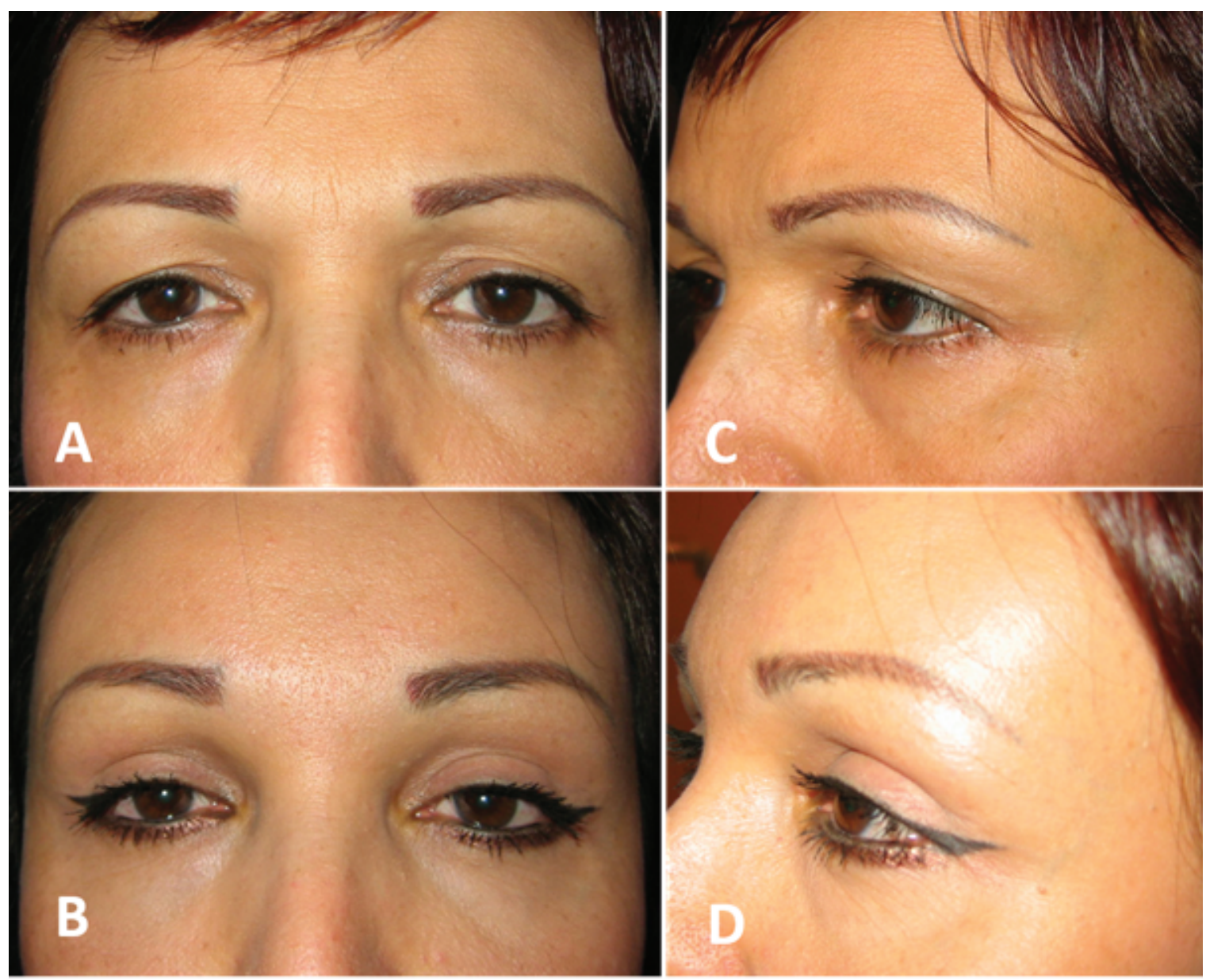

Figure 10. Before (A \& C) and two years after (B \& D) endoscopic forehead lift and upper blepharoplasty in a female in whom medial and lateral eyebrow lift are visible.
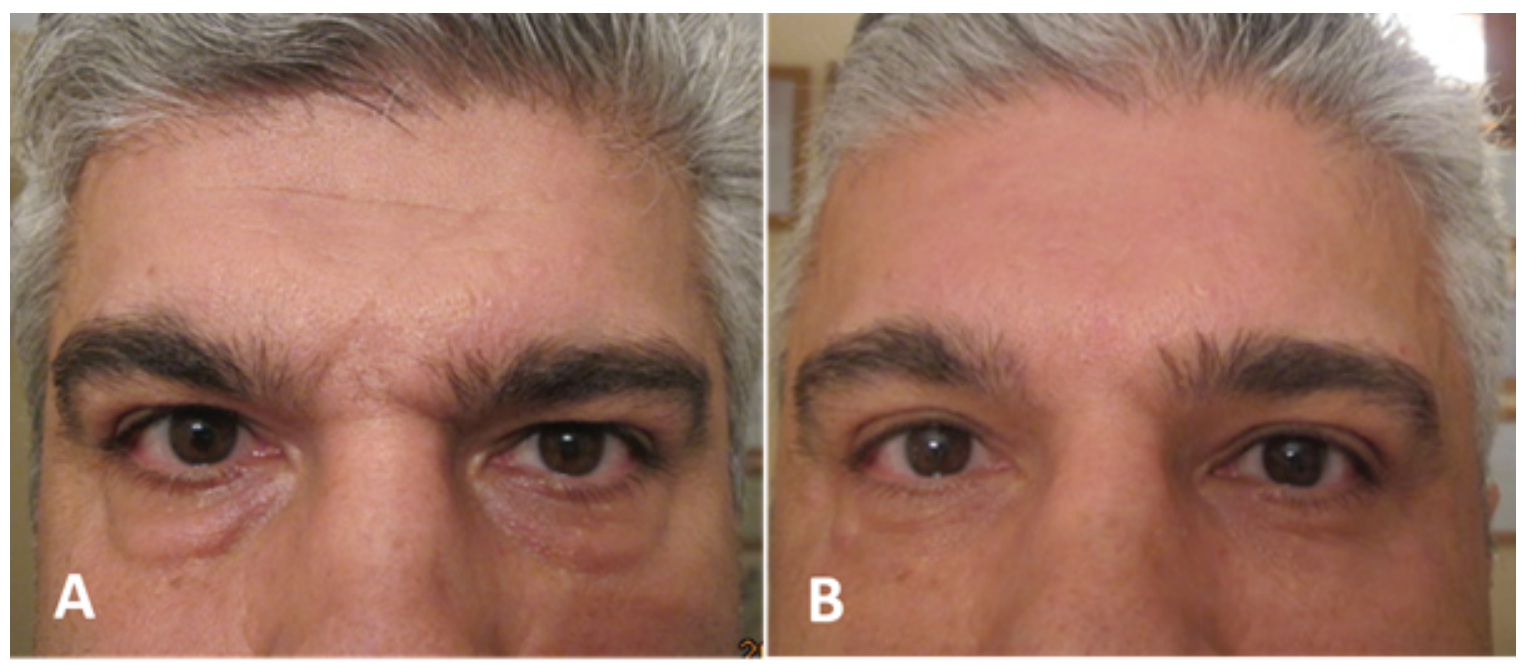

Figure 11. A male patient with good frontal hairline (A) who underwent endoscopic forehead lift and upper blepharoplasty procedures and ended up with a good eyebrow lift two and a half years after the surgery (B). 


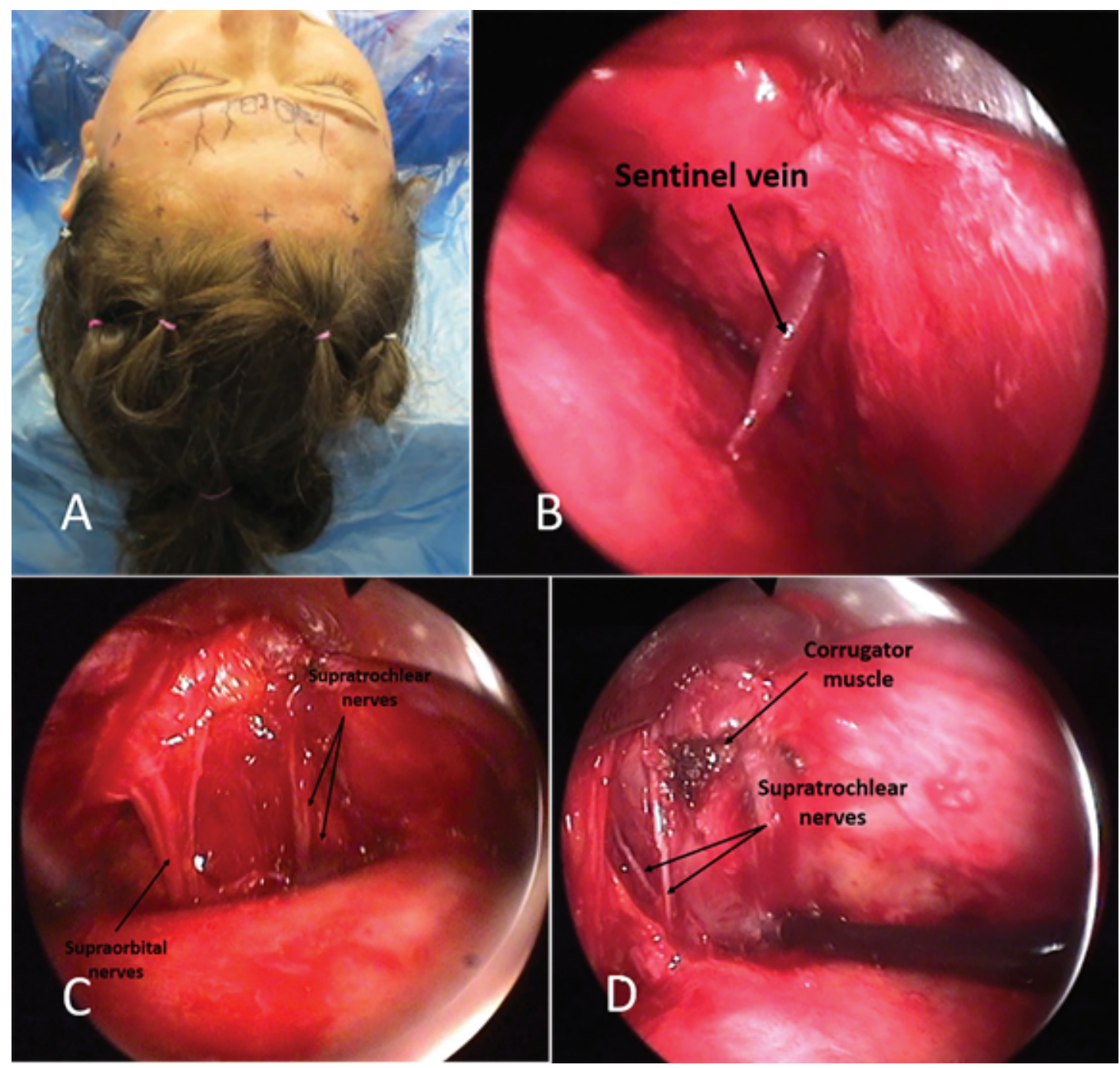

Figure 12. Endoscopic forehead lift. Novice surgeons are recommended to mark the location of corrugator muscles, supratrochlear and supraorbital neurovascular bundles before commencing the surgery (A). Sentinel vein is in close proximity to the frontal division of the facial nerve (B). Supratrochlear and supraorbital neurovascular bundles are readily identifiable during endoscopic lift (C). Corrugator muscle is disinserted and cauterized to smoothen the frown lines. Supratrochlear nerves crossing the muscle fibers should be preserved during the muscle disinsertion (D).

orbital rim down to the frontozygomatic suture line. Laterally, the dissection should proceed up to the conjoint tendon. Endoscope is helpful for safe dissection inferiorly below brow hairline ${ }^{[58]}$. Meticulous periosteal release and horizontal incision under direct visualization is crucial for an effective and symmetric elevation. The flap is then elevated to the desired level, and excess tissue is excised, followed by closure of the wound either by staples or sutures. The most common postoperative complications included scarring, brow asymmetry, and parenthesis of forehead and scalp. ${ }^{[59]}$

\section{Mid-forehead brow lift}

The mid-forehead brow lift is similar to the direct brow lift, except the incision is made in a deep transverse forehead crease rather than immediately above the eyebrow. This technique lowers the hairline by shortening the forehead. It is particularly effective in men with high or sparse frontal hairline and deep horizontal rhytids. The patient must be informed of the possible resultant visible scar for a long time. Dissection may be carried inferomedially to address the glabellar complex musculature, to improve central brow furrows. However, this 


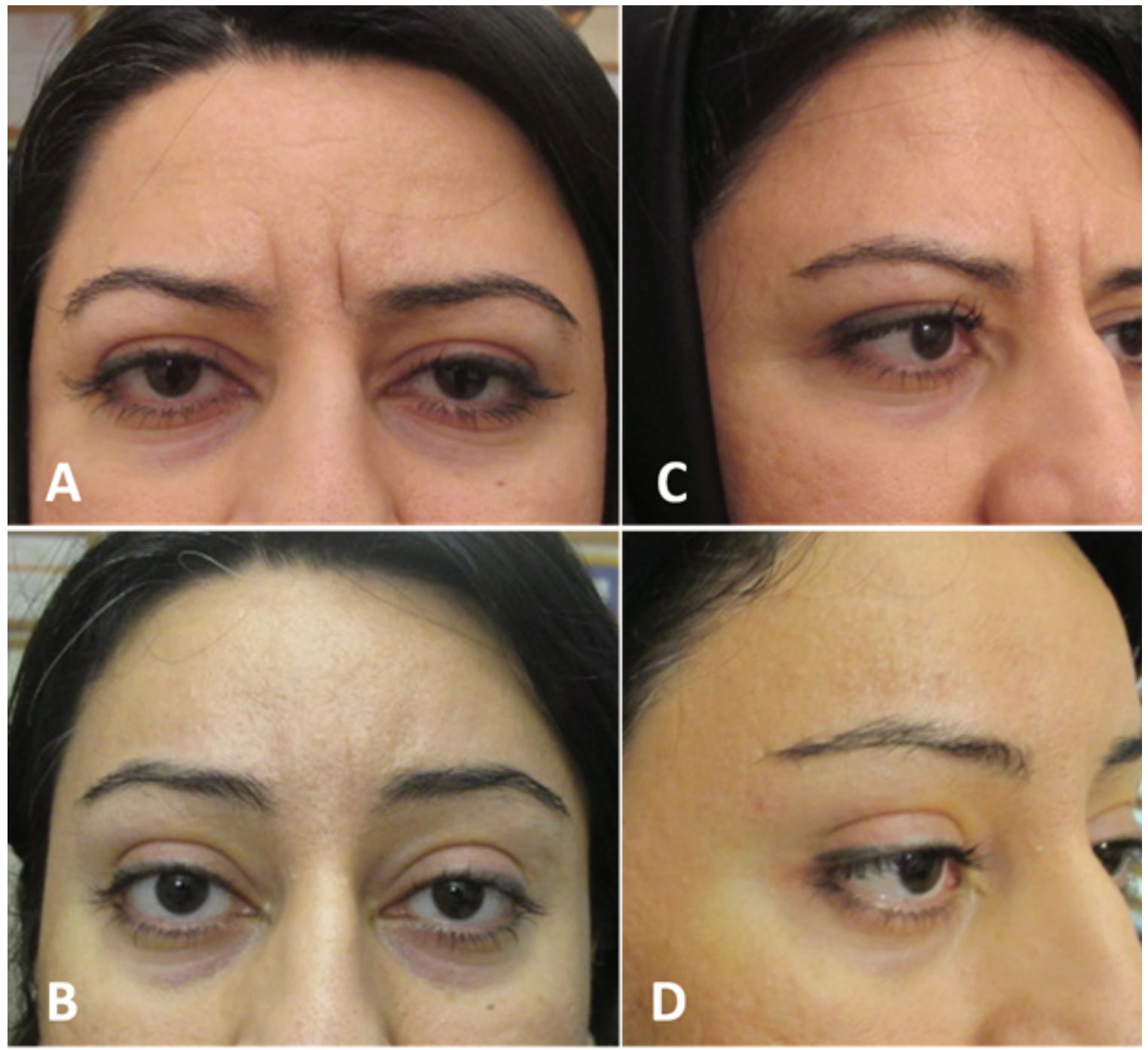

Figure 13. A patient with deep static glabellar lines (A \& C) who underwent endoscopic forehead lift with glabellar smoothening and resulted in total eyebrow lift and no glabellar lines (B \& D) one year after the procedure.

procedure does not improve horizontal forehead creases. $^{[42]}$

This review is an effort to provide an illustrated review of current popular techniques in brow lift. Although one may argue that limiting the search to PubMed or English language may have led to some personal techniques missed, the aim was to focus on the most commonly applied techniques (rather than trying to list all reported personal methods).

\section{SUMMARY}

The eyebrow complex is an integral aesthetic portion of the upper third of the face and the overall appearance of an individual. None of brow lift techniques are superior to the others. Therefore, facial surgeons should be familiar with all the techniques in order to recruit all in different subjects at different times. Non-surgical methods of forehead lift (BTA and filler) are temporary, need less experience, and in case of any complication, it is easier to correct. Transblepharoplasty and direct approaches can correct brow ptosis but not forehead wrinkles. A direct brow-lift is particularly useful in patients with facial palsy who need maximal elevation of the ptotic brow and are more likely to be accepting of the scar. Trans-forehead approaches can address both eyebrows and forehead. Currently, the most 

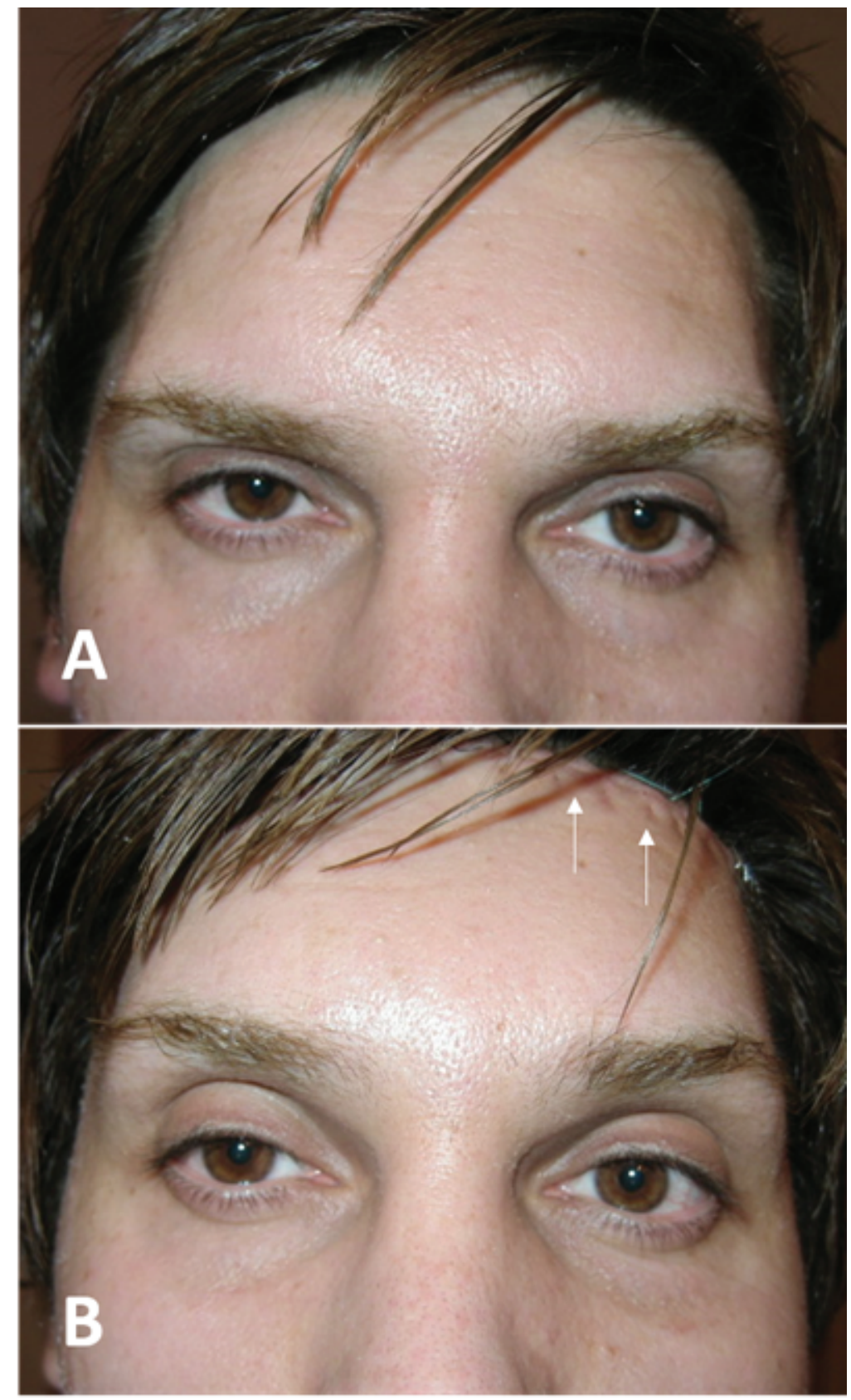

Figure 14. A young man with high hair line and total eyebrow ptosis (A) underwent pretrichial endoscopic forehead lift (B). While the lift effect is appreciated (B), scar of incision (arrows) will be visible for months and should be covered with hair styling.

popular is the endoscopic approach, but some surgeons are not trained in this procedure, it requires special equipment and in some cases the final outcome is modest and/or not longlasting.

\section{Financial Support and Sponsorship}

None.

\section{Conflicts of Interest}

There are no conflicts of interest.

\section{REFERENCES}

1. Kashkouli MB, Abolfathzadeh N, Abdolalizadeh P, Sianati $\mathrm{H}$, Karimi N. Upper blepharoplasty and eyebrow position. Expert Rev Ophthalmol 2017;12:251-259. 
2. Kashkouli MB, Abdolalizadeh P, Abolfathzadeh N, Sianati $H$, Sharepour M, Hadi Y. Periorbital facial rejuvenation: applied anatomy and pre-operative assessment. J Curr Ophthalmol 2017;29:154-168.

3. Kashkouli MB, Jamshidian-Tehrani M, Sharzad S, Sanjari MS. Upper blepharoplasty and lateral wound dehiscence. Middle East Afr J Ophthalmol 2015;22:452-456.

4. Kashkouli MB, Pakdel F, Kiavash V, Ghiasian L, Heirati A, Jamshidian-Tehrani M. Transconjunctival lower blepharoplasty: a 2-sided assessment of results and subjects' satisfaction. Ophthalmic Plast Reconstr Surg 2013;29:249255.

5. Kashkouli MB, Amani A, Jamshidian-Tehrani M, Yousefi S, Jazayeri AA. Eighteen-point abobotulinum toxin a upper face rejuvenation: an eye plastic perspective on 845 subjects. Ophthalmic Plast Reconstr Surg 2014;30:219224.

6. Ahn MS, Catten M, Maas CS. Temporal brow lift using botulinum toxin A. Plast Reconstr Surg 2000;105:11291135; discussion 1136-1129.

7. Raspaldo H, Gassia V, Niforos FR, Michaud T. Global, 3dimensional approach to natural rejuvenation: part 1 - recommendations for volume restoration and the periocular area. J Cosmet Dermatol 2012;11:279-289.

8. Sundaram $H$, Cassuto D. Biophysical characteristics of hyaluronic acid soft-tissue fillers and their relevance to aesthetic applications. Plast Reconstr Surg 2013;132:5S21S.

9. de Maio M, Swift A, Signorini M, Fagien S, Aesthetic Leaders in Facial Aesthetics Consensus C. Facial assessment and injection guide for botulinum toxin and injectable hyaluronic acid fillers: focus on the upper face. Plast Reconstr Surg 2017;140:265e-276e.

10. Chiang YZ, Pierone G, Al-Niaimi F. Dermal fillers: pathophysiology, prevention and treatment of complications. $J$ Eur Acad Dermatol Venereol 2017;31:405-413.

11. Kashkouli MB, Sharepour M, Sianati $H$, Abdolalizadeh P. Acute primary angle closure after periorbital facial procedures report of four cases and literature review. Orbit 2018;37:348-351.

12. Briceno CA, Zhang-Nunes SX, Massry GG. Minimally invasive surgical adjuncts to upper blepharoplasty. Facial Plast Surg Clin North Am 2015;23:137-151.

13. Hubbard BA, Unger JG, Rohrich RJ. Reversal of skin aging with topical retinoids. Plast Reconstr Surg 2014;133:481e490e.

14. McCord CD, Doxanas MT. Browplasty and browpexy: an adjunct to blepharoplasty. Plast Reconstr Surg 1990;86:248-254.

15. Broadbent T, Mokhktarzadeh A, Harrison A. Minimally invasive brow lifting techniques. Curr Opin Ophthalmol 2017;28:539-543.

16. Mokhtarzadeh A, Massry GG, Bitrian E, Harrison AR. Quantitative efficacy of external and internal browpexy performed in conjunction with blepharoplasty. Orbit 2017;36:102-109.

17. Baker MS, Shams PN, Allen RC. The quantitated internal suture browpexy: comparison of two brow-lifting techniques in patients undergoing upper blepharoplasty. Ophthalmic Plast Reconstr Surg 2016;32:204-206.
18. Burroughs JR, Bearden WH, Anderson RL, McCann JD. Internal brow elevation at blepharoplasty. Arch Facial Plast Surg 2006;8:36-41.

19. Eftekhari K, Peng GL, Landsberger H, Douglas R, Massry GG. The brow fat pad suspension suture: safety profile and clinical observations. Ophthalmic Plast Reconstr Surg 2018;34:7-12.

20. Zarem HA, Resnick JI, Carr RM, Wootton DG. Browpexy: lateral orbicularis muscle fixation as an adjunct to upper blepharoplasty. Plast Reconstr Surg 1997;100:1258-1261.

21. Tyers AG. Brow lift via the direct and trans-blepharoplasty approaches. Orbit 2006;25:261-265.

22. Clevens RA. Rejuvenation of the male brow. Facial Plast Surg Clin North Am 2008;16:299-312.

23. Pascali M, Bocchini I, Avantaggiato A, Carinci F, Cervelli V, Orlandi F, et al. Direct brow lifting: specific indications for a simplified approach to eyebrow ptosis. Indian J Plast Surg 2016;49:66-71.

24. Levine MR, Allen RC. Manual of oculoplastic surgery. 5th edition. Springer, New York; 2018.

25. Booth AJ, Murray A, Tyers AG. The direct brow lift: efficacy, complications, and patient satisfaction. $\mathrm{Br} \mathrm{J}$ Ophthalmol 2004;88:688-691.

26. Green JP, Goldberg RA, Shorr N. Eyebrow ptosis. Int Ophthalmol Clin 1997;37:97-122.

27. Ueda K, Harii K, Yamada A. Long-term follow-up study of browlift for treatment of facial paralysis. Ann Plast Surg 1994;32:166-170.

28. Lycka B, Bazan C, Poletti E, Treen B. The emerging technique of the antiptosis subdermal suspension thread. Dermatol Surg 2004;30:41-44; discussion 44.

29. Sulamanidze M, Sulamanidze G. APTOS suture lifting methods: 10 years of experience. Clin Plast Surg 2009;36:281-306.

30. Trevidic P, Alkebaisi A. [Facial threads for face lift]. Rev Laryngol Otol Rhinol (Bord) 2006;127:57-59.

31. Tavares JP, Oliveira C, Torres RP, Bahmad F Jr. Facial thread lifting with suture suspension. Braz J Otorhinolaryngol 2017;83:712-719.

32. Sulamanidze MA, Fournier PF, Paikidze TG, Sulamanidze GM. Removal of facial soft tissue ptosis with special threads. Dermatol Surg 2002;28:367-371.

33. Flynn J. Suture suspension lifts: a review. Oral Maxillofac Surg Clin North Am 2005;17:65-76.

34. Lee $\mathrm{H}$, Yoon K, Lee M. Outcome of facial rejuvenation with polydioxanone thread for Asians. J Cosmet Laser Ther 2018;20:189-192.

35. Rezaee Khiabanloo S, Jebreili R, Aalipour E, Saljoughi N, Shahidi A. Outcomes in thread lift for face and neck: a study performed with Silhouette Soft and Promo Happy Lift double needle, innovative and classic techniques. J Cosmet Dermatol 2019;18:84-93.

36. Gulbitti HA, Colebunders B, Pirayesh A, Bertossi D, van der Lei B. Thread-lift sutures: still in the lift? A systematic review of the literature. Plast Reconstr Surg 2018;141:341e-347e.

37. Rachel JD, Lack EB, Larson B. Incidence of complications and early recurrence in 29 patients after facial rejuvenation with barbed suture lifting. Dermatol Surg 2010;36:348354. 
38. Obourn CA, Williams EF 3rd. A decade of thread-lifting: what have we learned over the last 10 years? JAMA Facial Plast Surg 2018;20:349-350.

39. Tong LX, Rieder EA. Thread-lifts: a double-edged suture? A comprehensive review of the literature. Dermatol Surg 2019;45:931-940.

40. Paul MD. Complications of barbed sutures. Aesthetic Plast Surg 2008;32:149.

41. Winkler E, Goldan O, Regev E, Mendes D, Orenstein A, Haik J. Stensen duct rupture (sialocele) and other complications of the Aptos thread technique. Plast Reconstr Surg 2006;118:1468-1471.

42. McGuire CS, Gladstone HB. Novel pretrichial browlift technique and review of methods and complications. Dermatol Surg 2009;35:1390-1405.

43. Adamson PA, Johnson CM Jr, Anderson JR, Dupin CL. The forehead lift. A review. Arch Otolaryngol 1985;111:325329.

44. Withey $\mathrm{S}$, Witherow $\mathrm{H}$, Waterhouse N. One hundred cases of endoscopic brow lift. Br J Plast Surg 2002;55:20-24.

45. Dolsky RL. The forehead-brow lift - folding the flap to avoid bradycardia. Ann Plast Surg 1982;9:355.

46. Elkwood A, Matarasso A, Rankin M, Elkowitz M, Godek CP. National plastic surgery survey: brow lifting techniques and complications. Plast Reconstr Surg 2001;108:21432150; discussion 2151-2142.

47. Riefkohl R, Kosanin R, Georgiade GS. Complications of the forehead-brow lift. Aesthetic Plast Surg 1983;7:135-138.

48. Kashkouli MB, Beigi B. Endoscopy in the field of oculofacial plastic surgery. J Curr Ophthalmol 2018;30:99-101.
49. Codner MA, McCord CD. Eyelid \& periorbital surgery. 2nd ed. CRC Press, Florida; 2016

50. Yeatts RP. Current concepts in brow lift surgery. Curr Opin Ophthalmol 1997;8:46-50.

51. Chiu ES, Baker DC. Endoscopic brow lift: a retrospective review of 628 consecutive cases over 5 years. Plast Reconstr Surg 2003;112:628-633; discussion 634-625.

52. Viksraitis S, Astrauskas T, Karbonskiene A, Budnikas G. Endoscopic aesthetic facial surgery: technique and results. Medicina (Kaunas) 2004;40:149-155.

53. Cho MJ, Carboy JA, Rohrich RJ. Complications in brow lifts: a systemic review of surgical and nonsurgical brow rejuvenations. Plast Reconstr Surg Glob Open 2018;6:e1943.

54. Jones BM, Grover R. Endoscopic brow lift: a personal review of 538 patients and comparison of fixation techniques. Plast Reconstr Surg 2004;113:1242-1250; discussion 1251-1242.

55. Georgescu D, Anderson RL, McCann JD. Brow ptosis correction: a comparison of five techniques. Facial Plast Surg 2010;26:186-192.

56. Tabatabai N, Spinelli HM. Limited incision nonendoscopic brow lift. Plast Reconstr Surg 2007;119:1563-1570.

57. Fattahi T. Trichophytic brow lift: a modification. Int J Oral Maxillofac Surg 2015;44:371-373.

58. Tower RN, Dailey RA. Endoscopic pretrichial brow lift: surgical indications, technique and outcomes. Ophthalmic Plast Reconstr Surg 2004;20:268-273.

59. Owsley TG. Subcutaneous trichophytic forehead browlift: the case for an "open" approach. J Oral Maxillofac Surg 2006;64:1133-1136. 